\title{
Macroeconomic Determinants of Energy Consumption in BRICS (Brazil, Russia, India, China, South Africa)
}

\author{
Submitted 11/03/21, $1^{\text {st }}$ revision 17/04/21, $2^{\text {nd }}$ revision 08/05/21, accepted 25/05/21
}

\begin{abstract}
Kunofiwa Tsaurai ${ }^{1}$
Abstract:

Purpose: The study investigates the determinants of energy consumption in BRICS countries. Design/Methodology/Approach: The study is using panel data analysis methodology (fixed effects, FMOLS, pooled OLS, random effects) with panel data ranging from 1996 to 2018. Findings: Under fixed effects, financial development was found to have a significant positive influence on energy consumption in model 1 and a significant negative effect on energy consumption in model 3. Human capital development, financial development, the interaction between financial and human capital development and economic growth were all found to have had a significant positive influence on energy consumption across all the four models. FDI had a significant positive effect on energy consumption in model 1 and 2 whilst infrastructural development had a significant positive influence on energy consumption in model 1, 3 and 4. Under random effects, financial development influenced energy consumption in a significant positive manner in model 2 and 3. Both human capital development and the interaction term separately had a significant positive impact on energy consumption across all the four models whilst trade openness and infrastructural development's influence on energy consumption was positive and significant in model 1 and 3. Yet economic growth and FDI were found to have had a significant positive influence on energy consumption in model 1 and 4. Under FMOLS, four variables which had a significant positive effect on energy consumption across all the four models include human capital development, the interaction term, economic growth and infrastructural development.

Practical implications: BRICS countries are therefore urged to design and implement policies aimed at enhancing human capital development, the complementarity between financial and human capital development, economic growth, and infrastructural development in order to increase renewable and fossil fuel energy usage (energy usage that preserves the ecosystem and promotes sustainable growth).
\end{abstract}

Originality value: It considers the fact that the relationship between energy consumption and its determinants is not of a linear nature (is non-linear).

Keywords: Energy Consumption; Determinants; Panel Data; BRICS.

JEL codes: $C 1, C 4, C 5$.

Paper type: Research article.

\footnotetext{
${ }^{1}$ Associate Professor, Department of Finance, Risk Management and Banking, University of South Africa, South Africa kunofiwa.tsaurai@gmail.com
} 


\section{Introduction}

This section focuses on the background of the study, contribution of the study towards literature and organization of the study. Energy consumption is one of the critical and essential inputs into the production process that drives economic growth and enhances the economic wellbeing of the citizens (Samuel et al., 2013). According to Tang (2009), manufacturing activities, extraction activities in the primary sector of production, farming activities, infrastructural development, and maintenance activities, all of which are the pillar behind economic growth consumes energy. Altar and Syed (2011) argued that the reasons for the slow economic growth and development of African countries and Third World countries is inadequate supply of energy, inefficient energy usage devices, frequent energy power cuts, overdependence on external sources of energy and long fuel queues at service stations which eats into the productivity levels of the able-bodied personnel. Given the existence of unadulterated and conclusive evidence that energy consumption is one of the keys that unlocks economic growth of a country, effective economic growth policy formulation then hinges on the ability of researchers and policy makers to dissect the factors that influences energy consumption.

Theoretical literature that exists on the determinants of energy consumption (Table 1) does not agree on the direction of the impact of the variables on energy consumption. Population growth, human capital development, trade openness, economic growth, and financial development, among others are some of the macroeconomic variables whose influence on energy consumption produced mixed results (Table 1). Both theoretical and empirical literature (Table 2) fails to agree on a common list of macroeconomic variables that determines energy consumption. In particular, the conclusion of each empirical research on the determinants of energy consumption seems to be quite divergent from the rest of the other empirical studies on a similar subject matter. In fact, the result from the similar empirical research is divergent, mixed, and far from being close to providing a conclusive argument on the subject matter.

Majority of the empirical researchers on the determinants of energy consumption wrongly assumed that there is a linear relationship between energy consumption and its macroeconomic determinants. This study considers that the relationship does not follow a linear pattern. As a result, this study also investigated whether the complementarity between financial and human capital development enhances or reduces energy consumption in BRICS nations. Existing empirical research on the determinants of energy consumption have so far focused on other global economic groupings or individual countries. No such a study has been done focusing on BRICS, to the best knowledge of the author.

This study contributes to the literature in the following ways. Firstly, it uses the most recent data (1996-2018). Secondly, it considers the fact that the relationship between energy consumption and its determinants is not of a linear nature (is non-linear). 
Thirdly, it uses scenario analysis. In other words, the study is the first of its kind on the subject matter to use four different measures of energy consumption, namely energy use ( $\mathrm{kg}$ of oil equivalent per capita, renewable energy consumption (\% of total final energy consumption), electric power consumption (kWh per capita) and fossil fuel energy consumption (\% of total). Fourthly, it is the first study to the author's best knowledge to investigate the impact of the complementarity between financial and human capital development on energy consumption. Fifthly, no such study has so far been done using BRICS as a unit of analysis to the best of the author's knowledge.

Section 2 discusses the theoretical literature on the determinants of energy consumption whilst section 3 focuses on the empirical literature review of the determinants of energy consumption. Section 4 describes the framework of the research methodology. Section 5 analyses data, presents and discusses the results. Section 6 is the concluding remarks.

\section{Determinants of Energy Consumption-Theoretical Literature}

Table 1 summarizes various macroeconomic variables whose theoretical influence on energy consumption has been documented. The theoretical impact of each macroeconomic variable on energy consumption is discussed in Table 1 under the theory intuition column.

Table 1. Theoretical literature on the determinants of energy consumption

\begin{tabular}{|c|c|c|c|}
\hline Variable & Proxy used & Theory intuition & $\begin{array}{l}\text { Expe } \\
\text { cted } \\
\text { sign } \\
\end{array}$ \\
\hline $\begin{array}{l}\text { Financial } \\
\text { development } \\
(\text { FIN) }\end{array}$ & $\begin{array}{l}\text { Domestic } \\
\text { credit by } \\
\text { financial } \\
\text { sector ( } \% \text { of } \\
\text { GDP })\end{array}$ & $\begin{array}{l}\text { Consistent with Aye and Edoja (2017), developed } \\
\text { financial markets attracts foreign direct investment, } \\
\text { which increases the quantity of energy usage in the } \\
\text { host country. Financial development spurs the } \\
\text { number and scale of economic activities, hence } \\
\text { increasing the overall quantity of energy used in the } \\
\text { economy. Financial development can avail more } \\
\text { funding towards investment into clean energy } \\
\text { sources which are energy efficient (Aye and Edoja. } \\
\text { 2017). }\end{array}$ & $+/-$ \\
\hline $\begin{array}{l}\text { Economic } \\
\text { growth } \\
\text { (GROWTH) }\end{array}$ & $\begin{array}{l}\text { GDP per } \\
\text { capita }\end{array}$ & $\begin{array}{l}\text { Whilst Huang et al. (2008) noted that economic } \\
\text { growth has got a deleterious effect on energy } \\
\text { consumption, Nindi and Odhiambo (2014) argued } \\
\text { that in a more energy consumption reliant economy, } \\
\text { economic growth leads to more energy consumption. } \\
\text { This is because sustaining economic growth is } \\
\text { enhanced by heavy investment into more energy } \\
\text { consuming manufacturing activities. }\end{array}$ & $+/-$ \\
\hline
\end{tabular}




\begin{tabular}{|c|c|c|c|}
\hline $\begin{array}{l}\text { Trade openness } \\
\text { (OPEN) }\end{array}$ & $\begin{array}{l}\text { Exports of } \\
\text { goods and } \\
\text { services (\% of } \\
\text { GDP) }\end{array}$ & $\begin{array}{l}\text { In line with Rasiah et al. (2018), trade openness } \\
\text { allows firms to expand easily as they can now source } \\
\text { raw materials and supply their finished products } \\
\text { globally. As a result, energy usage triggered } \\
\text { production action activities go up. Grossman and } \\
\text { Krueger (1991) argued that trade openness enables } \\
\text { firms to be energy efficient as they can now easily } \\
\text { purchase new technology which uses less energy } \\
\text { from anywhere in the world. }\end{array}$ & $+1-$ \\
\hline $\begin{array}{l}\text { Foreign direct } \\
\text { investment (FDI) }\end{array}$ & $\begin{array}{l}\text { Net FDI } \\
\text { inflows (\% of } \\
\text { GDP) }\end{array}$ & $\begin{array}{l}\text { Inflow of foreign direct investment increases } \\
\text { urbanization, infrastructural development activities, } \\
\text { manufacturing activities and the rate of } \\
\text { industrialization. These activities increase energy } \\
\text { consumption, in line with (Tang, 2009). A study } \\
\text { done by Abdouli and Hammami (2017) came to a } \\
\text { similar conclusion. }\end{array}$ & + \\
\hline $\begin{array}{l}\text { Human capital } \\
\text { development } \\
\text { (HCD) }\end{array}$ & $\begin{array}{l}\text { Human capital } \\
\text { development } \\
\text { index }\end{array}$ & $\begin{array}{l}\text { Skilled and educated have the financial resources to } \\
\text { purchase new technology that is energy efficient. On } \\
\text { the other hand, high levels of human capital } \\
\text { development spur industrialization and large-scale } \\
\text { manufacturing activities in the economy, leading to } \\
\text { more energy consumption (Tsaurai, 2019). }\end{array}$ & $+1-$ \\
\hline $\begin{array}{l}\text { Population } \\
\text { growth (PG) }\end{array}$ & $\begin{array}{l}\text { Population } \\
\text { growth } \\
\text { (annual \%) }\end{array}$ & $\begin{array}{l}\text { According to Liu et al. (2015), governments are } \\
\text { forced to invest more into infrastructural } \\
\text { development and expansion activities (which uses } \\
\text { more energy) to satisfy the infrastructural needs of } \\
\text { the increased population. A study done by Liddle } \\
\text { (2004) however produced results which contradicted } \\
\text { this perspective. }\end{array}$ & $+/-$ \\
\hline $\begin{array}{l}\text { Infrastructure } \\
\text { development } \\
\text { (INFR) }\end{array}$ & $\begin{array}{l}\text { Fixed } \\
\text { telephone } \\
\text { subscription } \\
\text { (per } 100 \\
\text { people) }\end{array}$ & $\begin{array}{l}\text { Infrastructural development such as roads } \\
\text { maintenance, mining infrastructural maintenance, } \\
\text { buildings renovations constitute the major users of } \\
\text { energy in the economy (Reddy et al. 2001). The } \\
\text { view was supported by Yessengali and Murat } \\
\text { (2018). }\end{array}$ & + \\
\hline $\begin{array}{l}\text { Complementarit } \\
\text { y between } \\
\text { physical capital } \\
\text { investment } \\
\text { (financial } \\
\text { development) } \\
\text { and human } \\
\text { capital } \\
\text { development and }\end{array}$ & $\begin{array}{l}\text { Domestic } \\
\text { credit by } \\
\text { financial } \\
\text { sector (\% of } \\
\text { GDP) } \quad \text { x } \\
\text { Human capital } \\
\text { development } \\
\text { index. }\end{array}$ & $\begin{array}{l}\text { According to Salim et al. (2017), financial markets } \\
\text { can avail financial resources towards the } \\
\text { development of new technology by skilled people. } \\
\text { The same study noted that the new smart technology } \\
\text { leads to an increase in the usage of clean energy in } \\
\text { the economy. }\end{array}$ & $+1-$ \\
\hline
\end{tabular}

Source: Author compilation.

Looking at Table 1, the impact of the macroeconomic variables on energy consumption is still inconclusive. This is because available literature on the subject matter is mixed, divergent and does not agree on the direction of causality. The gap in the literature motivated this study.

\section{Determinants of Energy Consumption-Empirical Literature}


Table 2 below summarizes the available empirical literature on various macroeconomic factors that influence energy consumption.

Table 2. Determinants of energy consumption - Empirical literature

\begin{tabular}{|c|c|c|c|c|}
\hline Author & $\begin{array}{l}\text { Country/Coun } \\
\text { tries of study }\end{array}$ & Period & Methodology & Results \\
\hline $\begin{array}{l}\text { Samuel et } \\
\text { al. (2013) }\end{array}$ & Worldwide & $\begin{array}{l}\text { Not } \\
\text { applic } \\
\text { able }\end{array}$ & $\begin{array}{l}\text { Literature } \\
\text { review } \\
\text { analysis }\end{array}$ & $\begin{array}{l}\text { Economic growth, price of electricity, } \\
\text { financial development, price of substitutes, } \\
\text { air temperature, population growth and } \\
\text { industrial development and efficiency were } \\
\text { found to have had a significant influence } \\
\text { on energy consumption. }\end{array}$ \\
\hline $\begin{array}{l}\text { Azam et } \\
\text { al. }(2016)\end{array}$ & Greece & $\begin{array}{l}1975- \\
2013\end{array}$ & $\begin{array}{l}\text { Vector Error } \\
\text { Correction } \\
\text { Model } \\
\text { (VECM) }\end{array}$ & $\begin{array}{l}\text { Infrastructural development, population } \\
\text { growth, urbanization, trade openness, } \\
\text { foreign direct investment and economic } \\
\text { growth were found to be the major } \\
\text { determinants of energy consumption in } \\
\text { Greece. }\end{array}$ \\
\hline $\begin{array}{l}\text { Fuerst et } \\
\text { al. }(2020)\end{array}$ & $\begin{array}{l}\text { United } \\
\text { Kingdom }\end{array}$ & $\begin{array}{l}\text { Surve } \\
\text { y data } \\
(2011- \\
2013)\end{array}$ & $\begin{array}{l}\text { Descriptive } \\
\text { statistics and } \\
\text { multiple } \\
\text { ordinary least } \\
\text { squares } \\
\text { approach }\end{array}$ & $\begin{array}{l}\text { Size of the household, income level of the } \\
\text { household and employment status of the } \\
\text { household are the three key factors which } \\
\text { were found to have had a significant } \\
\text { influence on energy consumption (gas } \\
\text { usage) in the United Kingdom. }\end{array}$ \\
\hline $\begin{array}{l}\text { Xia and } \\
\mathrm{Hu} \\
(2012)\end{array}$ & $\begin{array}{l}\text { Chinese } \\
\text { provinces }\end{array}$ & $\begin{array}{l}2009 \\
\text { survey } \\
\text { data }\end{array}$ & $\begin{array}{l}\text { Descriptive } \\
\text { statistics }\end{array}$ & $\begin{array}{l}\text { Urban concentration, electricity intensity, } \\
\text { urbanization rate and the price of } \\
\text { electricity were found to have had a } \\
\text { significant influence on electricity } \\
\text { consumption across Chinese provinces. }\end{array}$ \\
\hline $\begin{array}{l}\text { Zaharia et } \\
\text { al. (2019) }\end{array}$ & $\begin{array}{l}\text { European } \\
\text { Union } \\
\text { countries }\end{array}$ & $\begin{array}{l}1995- \\
2019\end{array}$ & $\begin{array}{ll}\text { Panel data } \\
\text { analysis }\end{array}$ & $\begin{array}{l}\text { Gross domestic product, greenhouse gas } \\
\text { emissions, rate of labour growth had a } \\
\text { positive influence on energy consumption. } \\
\text { Factors which were found to have had a } \\
\text { negative effect on energy consumption } \\
\text { include energy taxes, healthcare } \\
\text { expenditure increase and feminine } \\
\text { population increase. }\end{array}$ \\
\hline $\begin{array}{l}\text { Sinevicie } \\
\text { ne et al. } \\
(2017)\end{array}$ & $\begin{array}{l}\text { Eastern } \\
\text { Europe }\end{array}$ & $\begin{array}{l}1996- \\
2013\end{array}$ & $\begin{array}{ll}\text { Panel data } \\
\text { analysis }\end{array}$ & $\begin{array}{l}\text { Economic growth was found to be a major } \\
\text { factor behind the increase in energy } \\
\text { consumption. Carbon emissions per capita, } \\
\text { fixed capital and share of the industry in } \\
\text { the economy were observed to have } \\
\text { increased energy efficiency in Eastern } \\
\text { Europe. }\end{array}$ \\
\hline $\begin{array}{l}\text { Kwakwa } \\
\text { (2018) }\end{array}$ & Benin & $\begin{array}{l}1971- \\
2014\end{array}$ & $\begin{array}{l}\text { Ordinary } \\
\text { Least Squares }\end{array}$ & $\begin{array}{l}\text { Levels of income reduced electricity } \\
\text { consumption whilst population, education, } \\
\text { urbanization, and industrialization increase } \\
\text { had a positive effect on electricity } \\
\text { consumption in Behin. }\end{array}$ \\
\hline $\begin{array}{l}\text { Kim } \\
(2018)\end{array}$ & Korea & $\begin{array}{l}2015 \\
\text { survey } \\
\text { data }\end{array}$ & $\begin{array}{l}\text { Descriptive } \\
\text { statistics }\end{array}$ & $\begin{array}{l}\text { Number and type of household electrical } \\
\text { appliances were found to be the major } \\
\text { determinants of household electricity } \\
\text { consumption in Korea. }\end{array}$ \\
\hline
\end{tabular}




\begin{tabular}{|c|c|c|c|c|}
\hline $\begin{array}{l}\text { Inglesi- } \\
\text { Lotz and } \\
\text { Pouris } \\
(2016)\end{array}$ & South Africa & $\begin{array}{l}1981- \\
2011\end{array}$ & $\begin{array}{l}\text { Descriptive } \\
\text { statistics }\end{array}$ & $\begin{array}{l}\text { Economic growth had a significant positive } \\
\text { impact on energy consumption in South } \\
\text { Africa. }\end{array}$ \\
\hline $\begin{array}{l}\text { Ateba et } \\
\text { al. }(2018)\end{array}$ & South Africa & $\begin{array}{l}2016 \\
\text { survey } \\
\text { data }\end{array}$ & $\begin{array}{l}\text { Descriptive } \\
\text { statistics }\end{array}$ & $\begin{array}{l}\text { Household income, household size, gender } \\
\text { and level of education were the variables } \\
\text { which had a significant effect on household } \\
\text { energy consumption in South Africa. }\end{array}$ \\
\hline $\begin{array}{l}\text { Fernandes } \\
\text { and } \\
\text { Reddy } \\
(2021)\end{array}$ & $\begin{array}{l}\text { Newly } \\
\text { industrialized } \\
\text { countries of } \\
\text { Asia }\end{array}$ & $\begin{array}{l}1980- \\
2018\end{array}$ & VECM & $\begin{array}{l}\text { In China, energy consumption was } \\
\text { increased by factors such as } \\
\text { industrialization, financial development, } \\
\text { exchange rate and trade openness. } \\
\text { Industrialization is the only variable which } \\
\text { increased energy consumption in Thailand } \\
\text { and India. Economic growth spurred } \\
\text { energy consumption in Indonesia whilst } \\
\text { energy consumption was increased by trade } \\
\text { openness in the case of Malaysia. }\end{array}$ \\
\hline $\begin{array}{l}\text { Rahut et } \\
\text { al. (2017) }\end{array}$ & Timor-Leste & $\begin{array}{l}2007 \\
\text { survey } \\
\text { data }\end{array}$ & $\begin{array}{l}\text { Descriptive } \\
\text { statistics }\end{array}$ & $\begin{array}{l}\text { Urban households, wealthy households } \\
\text { and highly educated households were } \\
\text { likely to use more energy. }\end{array}$ \\
\hline $\begin{array}{l}\text { Ergun et } \\
\text { al. }(2019)\end{array}$ & Africa & $\begin{array}{l}1990- \\
2013\end{array}$ & $\begin{array}{ll}\text { Panel data } \\
\text { analysis }\end{array}$ & $\begin{array}{l}\text { African countries with higher levels of } \\
\text { economic growth and human capital } \\
\text { development used less renewable energy } \\
\text { whilst African countries characterised by } \\
\text { higher levels of foreign direct investment } \\
\text { used significant amount of renewable } \\
\text { energy. }\end{array}$ \\
\hline $\begin{array}{l}\text { Mehrara } \\
\text { et al. } \\
(2015)\end{array}$ & $\begin{array}{l}\text { Economic } \\
\text { Cooperation } \\
\text { Organization } \\
\text { (ECO) } \\
\text { countries }\end{array}$ & $\begin{array}{l}1992- \\
2011\end{array}$ & $\begin{array}{ll}\text { Panel data } \\
\text { analysis }\end{array}$ & $\begin{array}{l}\text { Urban population and human capital } \\
\text { development determined renewable energy } \\
\text { consumption to a greater extent in ECO } \\
\text { countries. Renewable potential and } \\
\text { availability of renewable resources also } \\
\text { influenced renewable energy use in ECO } \\
\text { countries. }\end{array}$ \\
\hline $\begin{array}{l}\text { Sofia et } \\
\text { al. (2019) }\end{array}$ & EU countries & $\begin{array}{l}2000- \\
2016\end{array}$ & $\begin{array}{ll}\text { Panel data } \\
\text { analysis }\end{array}$ & $\begin{array}{l}\text { Population growth, high wealth levels and } \\
\text { cold weather conditions were found to } \\
\text { have had a positive effect on residential } \\
\text { energy consumption in the EU countries } \\
\text { studied. }\end{array}$ \\
\hline $\begin{array}{l}\text { Premaku } \\
\text { mara } \\
(2013)\end{array}$ & Karnataka & $\begin{array}{l}1997- \\
2010\end{array}$ & $\begin{array}{l}\text { Time series } \\
\text { analysis }\end{array}$ & $\begin{array}{l}\text { Size of the family and the region were the } \\
\text { most important factors found to have } \\
\text { determined energy consumption. }\end{array}$ \\
\hline $\begin{array}{l}\text { Lefevre } \\
\text { and } \\
\text { Mainguy } \\
(2020)\end{array}$ & World-wide & $\begin{array}{l}\text { Not } \\
\text { applic } \\
\text { able }\end{array}$ & $\begin{array}{l}\text { Literature } \\
\text { review } \\
\text { analysis }\end{array}$ & $\begin{array}{l}\text { Population growth, income levels, } \\
\text { education levels, financial development } \\
\text { and industrialization are the main variables } \\
\text { found to have a significant influence on } \\
\text { energy consumption. }\end{array}$ \\
\hline $\begin{array}{l}\text { Bohlman } \\
\mathrm{n} \quad \text { and } \\
\text { Inglesi- } \\
\text { Lotz } \\
(2020) \\
\end{array}$ & South Africa & $\begin{array}{l}1975- \\
2016\end{array}$ & $\begin{array}{l}\text { Autoregressiv } \\
\text { e Distributive } \\
\text { Lag }\end{array}$ & $\begin{array}{l}\text { High income levels increased energy } \\
\text { consumption whilst price of electricity } \\
\text { reduced energy consumption in South } \\
\text { during the period under study. }\end{array}$ \\
\hline
\end{tabular}




\begin{tabular}{|l|l|l|l|l|}
\hline $\begin{array}{l}\text { Elimam } \\
(2020)\end{array}$ & Saudi Arabia & $\begin{array}{l}1970- \\
2017\end{array}$ & $\begin{array}{l}\text { Descriptive } \\
\text { statistics }\end{array}$ & $\begin{array}{l}\text { Renewable energy sources reduced the } \\
\text { overall quantity of energy consumption in } \\
\text { Saudi Arabia }\end{array}$ \\
\hline $\begin{array}{l}\text { Ismail et } \\
\text { al. (2017) }\end{array}$ & $\begin{array}{l}\text { Association of } \\
\text { Southeast } \\
\text { Asian Nations } \\
\text { (ASEAN) } \\
\text { seven member } \\
\text { countries }\end{array}$ & 2015 & VECM & $\begin{array}{l}\text { High level of exports and economic growth } \\
\text { increased energy consumption in ASEAN } \\
\text { countries. }\end{array}$ \\
\hline
\end{tabular}

Source: Author compilation.

The results from the empirical studies on the determinants of energy consumption are diverse, mixed, and contradictory. It is clear from the existing empirical literature on the subject matter that a common list of the determinants of energy consumption is non-existent. In other words, the research focus area on the determinants of energy consumption is still far from being conclusive. It is against this backdrop that this empirical study intends to contribute on the subject matter by focusing on BRICS group of countries.

\section{Research Methodology -Framework Description}

Consistent with earlier similar empirical research done by Yessengali and Murat (2018), the energy consumption function is presented in equation 1.

$\mathrm{ENCONS}=\mathrm{f}(\mathrm{FIN}, \mathrm{HCD}, \mathrm{OPEN}, \mathrm{GROWTH}, \mathrm{FDI}, \mathrm{INFR})$

where ENCONS, FIN, HCD, OPEN, GROWTH, FDI and INFR respectively stands for energy consumption, financial development, human capital development, trade openness, economic growth, foreign direct investment and infrastructural development. ENCONS is measured by four proxies, namely energy use (kg of oil equivalent per capita), electric power consumption ( $\mathrm{kWh}$ per capita), renewable energy consumption (\% of total final energy consumption) and fossil fuel energy consumption (\% of total). Financial development is proxied by domestic credit by financial sector (\% of GDP), human capital development index is used to measure human capital development whilst trade openness is measured by total export of goods and services (\% of GDP) in this study. Gross domestic product (GDP) per capita, net FDI inflows (\% of GDP) and fixed telephone subscription (per 100 people) were used as measures of economic growth, foreign direct investment, and infrastructural development, respectively. In econometric terms, equation 1 is transformed into equation 2 below.

$$
\begin{aligned}
& \mathrm{ENCONS}_{\mathrm{it}}=\beta_{0}+\beta_{1} \mathrm{FIN}_{\mathrm{it}}+\beta_{2} \mathrm{HCD}_{\mathrm{it}}+\beta_{3}\left(\mathrm{FIN}_{\mathrm{it}} \mathrm{HCD}_{\mathrm{it}}\right)+\beta_{4} \mathrm{OPEN}_{\mathrm{it}}+\beta_{5} \mathrm{GROWTH}_{\mathrm{it}}+\beta_{6} \mathrm{FDI}_{\mathrm{it}} \\
& +\beta_{7} \mathrm{INFR}_{\mathrm{it}}+\mu+\varepsilon
\end{aligned}
$$


Whilst $\beta_{0}$ is an intercept, $\beta_{1}, \beta_{2}, \beta_{3}, \beta_{4} \beta_{5}, \beta_{6}$ and $\beta_{7}$ are coefficients for financial development, human capital development, the complementarity between financial development and human capital development, trade openness, economic growth, foreign direct investment and infrastructural development respectively. A significant positive value of $\beta_{3}$ means that the complementarity between financial development and human capital development increases energy consumption whilst a significant negative value of $\beta_{3}$ shows that the complementarity between the two variables has got a deleterious effect on energy consumption in BRICS. Four panel methods of data analysis are used in this study, namely fixed effects, random effects, pooled ordinary least squares (OLS) and the fully modified ordinary least squares (FMOLS).

\section{Data Analysis, Results Presentation and Discussion}

Panel data ranging from 1996 to 2018 was used for this study. The data was extracted from reputable international sources such as World Bank Development Indicators, African Development Indicators, International Monetary Fund and United Nations Development Programme. This section covers pre-estimation diagnostics and the main data analysis.

\subsection{Trend Analysis of Mean Values of the Variables Used}

Table 3 presents mean trend analysis (1996-2018) results of all the variables that were used in the study. These include energy consumption, financial development, human capital development, trade openness, economic growth, foreign direct investment, and infrastructural development. For trend analysis, energy use ( $\mathrm{kg}$ of oil equivalent per capita) was used as a measure of energy consumption.

Table 3. Mean trend analysis of the variables used in the study (1996-2018)

\begin{tabular}{|l|l|l|l|l|l|l|l|}
\hline & ENCONS & FIN & HCD & OPEN & GROWTH & FDI & INFR \\
\hline Brazil & 1277.86 & 86.11 & 0.75 & 12.00 & 10149 & 3.07 & 19.30 \\
\hline Russia & 4635.98 & 38.71 & 0.79 & 31.21 & 9254 & 2.07 & 25.52 \\
\hline India & 511.28 & 65.43 & 0.58 & 18.25 & 1233 & 1.45 & 2.74 \\
\hline China & 1582.58 & 141.24 & 0.72 & 24.59 & 3862 & 3.33 & 17.26 \\
\hline South Africa & 2635.65 & 169.06 & 0.67 & 28.71 & 6825 & 1.51 & 9.55 \\
\hline Overall mean & $\mathbf{2 1 2 8 . 6 7}$ & $\mathbf{1 0 0 . 1 1}$ & $\mathbf{0 . 7 0}$ & $\mathbf{2 2 . 9 5}$ & $\mathbf{6 2 6 4 . 5 5}$ & $\mathbf{2 . 2 8}$ & $\mathbf{1 4 . 8 7}$ \\
\hline
\end{tabular}

Source: Author's compilation.

Only Russia and South Africa had their mean energy consumption values greater than the overall mean energy consumption value of $2128.67 \mathrm{~kg}$ of oil equivalent per capita whilst the remining BRICS nations' mean energy consumption values were less than the overall mean energy consumption figure. Judging by the deviation between individual country's mean energy consumption values and the overall mean energy consumption figure, outliers include Russia, India, and Brazil. Regarding 
financial development, Brazil, Russia, and India's mean values were lower than the overall mean financial development of $100.11 \%$ of GDP. South Africa, Brazil and Russia are outliers because their mean financial development values are far away from the overall mean financial development value of $100.11 \%$ of GDP.

Brazil (0.75), Russia (0.79) and China (0.72)'s mean human capital development values are greater than the overall mean human capital development index value of 0.70. On the other hand, India (0.58) and South Africa (0.67)'s mean human capital development values are less than the overall mean human capital development index of 0.70. India and South Africa are the outliers because their mean human capital development values deviated from the overall mean human capital development index by a wider margin. Regarding trade openness, Russia (31.21\% of GDP), China (24.59\% of GDP) and South Africa (28.71\% of GDP) are the only BRICS nations whose mean trade openness values exceeded the overall mean trade openness value of $22.95 \%$ of GDP. In summary, Brazil (12\% of GDP), Russia (31.21\% of GDP) and South Africa (28.71\% of GDP) are the outliers because their mean trade openness values deviated by a wider margin from the overall mean trade openness value of $22.95 \%$ of GDP.

Among BRICS nations, only India (US\$1 233 per capita) and China (US\$3 862 per capita) had their mean GDP per capita values less than the overall mean GDP per capita value of US\$6 264.55. Considering mean GDP per capita values of the BRICS nations, only South Africa is not an outlier as the mean GDP per capita values of the remaining countries within the group deviated from the overall mean GDP per capita value by a very wide margin. Russia (2.07\% of GDP), India (1.45\% of GDP) and South Africa (1.51\% of GDP)'s mean FDI figures shows that they are below the overall mean FDI value of $2.28 \%$ of GDP.

The remaining BRICS nations (Brazil and China) had their mean FDI values greater than the overall mean FDI value of $2.28 \%$ of GDP. It is evident from Table 3 that Brazil, India, and China are the outliers because the deviation between their mean FDI values and the overall mean FDI value of $2.28 \%$ of GDP is exceptionally large.

Finally, Brazil, Russia and China are the only BRICS nations whose mean infrastructural development values surpassed the overall mean infrastructural development value of 14.87 fixed telephone subscriptions per 100 people. Using similar reasoning, Russia, India, and South Africa are the outliers regarding infrastructural development among BRICS nations.

\subsection{Correlation Analysis}

Table 4 presents correlation results between and among all the variables studied. The energy consumption proxy used in doing correlation analysis is energy use (kg of oil equivalent per capita). 
Table 4. Correlation results

\begin{tabular}{|l|l|l|l|l|l|l|l|}
\hline & ENCONS & FIN & HCD & OPEN & GROWTH & FDI & INFR \\
\hline ENCONS & 1.00 & & & & & & \\
\hline FIN & $0.0204^{*}$ & 1.00 & & & & & \\
\hline HCD & $0.2381^{*}$ & 0.0176 & 1.00 & & & & \\
\hline OPEN & $0.4517^{* *}$ & $0.1753^{*}$ & 0.1275 & 1.00 & & & \\
\hline GROWTH & $0.0023^{* * *}$ & $0.1125^{* *}$ & 0.1177 & -0.1276 & 1.00 & & \\
\hline FDI & $0.1287^{* *}$ & $0.0005^{* * *}$ & $0.2275^{*}$ & 0.7248 & $0.0126^{* * *}$ & 1.00 & \\
\hline INFR & $0.2381^{* * *}$ & $0.3218^{*}$ & $0.3427^{* *}$ & 0.4314 & $0.1893^{* * *}$ & $0.3327^{* *}$ & 1.00 \\
\hline
\end{tabular}

Note: $* * * / * * *$ denotes statistical significance at the $1 \% / 5 \% / 10 \%$ level, respectively.

Source: Author's compilation from E-Views.

The only correlation which is above $70 \%$ is between FDI and trade openness. In line with Aye and Edoja (2017), multicollinearity problem exists in the correlation between FDI and trade openness, understandably because they both measure the overall openness of the economy. Energy consumption was found to be significantly and positively correlated separately with financial development, human capital development, trade openness, economic growth, foreign direct investment, and infrastructural development. These results are supported by literature. To decisively address the multicollinearity problem and the issue of outliers, this study transformed all the data sets into natural logarithms before analysing it, consistent with other authors who had to deal with similar challenges (Aye and Edoja, 2017; Tsaurai, 2018).

\subsection{Panel Unit Root Tests}

Levin et al. (2002), Augmented Dick Fuller Fisher Chi Square, Im et al. (2003) and Phillip Peron (PP) Chi square tests approaches are used for panel unit root testing.

Table 5. Panel root tests-Individual intercept

\begin{tabular}{|c|c|c|c|c|}
\hline \multicolumn{5}{|l|}{ Level } \\
\hline & LLC & IPS & $\mathrm{ADF}$ & PP \\
\hline ENCONS & -2.2454 & -0.2546 & 10.0210 & 5.4542 \\
\hline FIN & -1.3526 & 0.5519 & 7.3492 & 5.2109 \\
\hline $\mathrm{HCD}$ & $-2.3782 * *$ & $-2.4592 * * *$ & $22.0819 * *$ & $35.8816 * * *$ \\
\hline OPEN & 1.9815 & 3.1916 & 1.7128 & 0.8501 \\
\hline GROWTH & -0.7591 & -0.0183 & 8.3820 & 7.4591 \\
\hline FDI & $-1.8137 * *$ & $-3.9329 * * *$ & $27.1483^{* * *}$ & $75.9491 * * *$ \\
\hline INFR & -1.1173 & $-1.7814^{*}$ & $20.8330 * *$ & 10.7811 \\
\hline \multicolumn{5}{|c|}{ First difference } \\
\hline ENCONS & $-4.4581 * *$ & $-3.9832 * * *$ & $37.4719 * * *$ & $128.1128 * * *$ \\
\hline FIN & $-2.9923 * * *$ & $-4.5618 * * *$ & $35.4592 * * *$ & $201.4502 * * *$ \\
\hline HCD & $-1.5491^{*}$ & $-3.9912 * * *$ & $33.8712 * * *$ & $317.3289 * * *$ \\
\hline OPEN & $-2.6721 * *$ & $-1.9910 * *$ & $18.8712^{* *}$ & $28.4501 * * *$ \\
\hline GROWTH & $-2.9911 * * *$ & $-3.4592 * * *$ & $29.6618^{* * * *}$ & $59.4591 * * *$ \\
\hline FDI & $-5.6615 * * *$ & $-5.4430 * * *$ & $45.8612 * * *$ & $172.9982 * * *$ \\
\hline INFR & $-2.8713 * * *$ & $-3.8821 * * *$ & $34.9943 * * *$ & $58.8734 * * *$ \\
\hline
\end{tabular}

Source: Author's compilation from E-Views. 
Note: LLC, IPS, ADF and PP stands for Levin, Lin and Chu; Im, Pesaran and Shin; ADF Fisher Chi Square and PP Fisher Chi Square tests respectively. *, ** and *** denote 10\%, $5 \%$ and $1 \%$ levels of significance, respectively.

Unlike at level, all variables used are integrated of order 1 at first difference. These results paved way for panel co-integration tests to be undertaken, consistent with Tembo (2018).

\subsection{Panel Co-integration Tests}

Table 6 presents results for panel co-integration which was done using Johansen Fisher Panel co-integration approach.

Table 6. Johansen Fisher Panel Co-integration test

\begin{tabular}{|l|l|l|l|l|}
\hline $\begin{array}{l}\text { Hypothesised No. } \\
\text { of CE(s) }\end{array}$ & $\begin{array}{l}\text { Fisher Statistic } \\
\text { (from trace test) }\end{array}$ & Probability & $\begin{array}{l}\text { Fisher Statistic } \\
\text { (from } \\
\text { eigen test) }\end{array}$ & Probability \\
\hline None & 6.8812 & 0.8121 & 6.712 & 0.7123 \\
\hline At most 1 & 6.882 & 0.8121 & 6.712 & 0.7123 \\
\hline At most 2 & 2.4371 & 0.9219 & 54.14 & 0.0000 \\
\hline At most 3 & 92.34 & 0.0000 & 91.25 & 0.0000 \\
\hline At most 4 & 160.4 & 0.0000 & 106.7 & 0.0000 \\
\hline At most 5 & 82.11 & 0.0000 & 58.93 & 0.0000 \\
\hline At most 6 & 31.76 & 0.0002 & 31.23 & 0.0002 \\
\hline
\end{tabular}

Source: Author's compilation from E-Views.

Six co-integrating vectors among the variables were observed. In other words, the null hypothesis which says that there is a long run relationship between and or among the variables studied could not be rejected at one percent significance level.

\subsection{Main Data Analysis}

In the main data analysis, model 1 uses energy use ( $\mathrm{kg}$ of oil equivalent per capita) as a measure of energy consumption whilst model 2 uses electric power consumption (kWh per capita) to proxy energy consumption. Renewable energy consumption (\% of total final energy consumption) is a measure of energy consumption used in model 3. Fossil fuel energy consumption ( $\%$ of total) was used in model 4 as a measure of energy consumption. Fixed effects results are presented in Table 7.

Table 7. Fixed Effects results

\begin{tabular}{|l|l|l|l|l|}
\hline & Model 1 & Model 2 & Model 3 & Model 4 \\
\hline FIN & $0.0067^{* *}$ & 0.2317 & $-0.4376^{*}$ & -0.2143 \\
\hline HCD & $0.1276^{*}$ & $0.4539^{*}$ & $0.0215^{*}$ & $0.2187^{* *}$ \\
\hline FIN.HCD & $0.4328^{* *}$ & $0.1165^{* *}$ & $0.2328^{* *}$ & $0.4586^{* *}$ \\
\hline OPEN & 0.4376 & 0.5329 & 0.3418 & 0.3217 \\
\hline GROWTH & $0.0328^{*}$ & $0.7523^{*}$ & $0.5428^{*}$ & $0.3365^{* *}$ \\
\hline FDI & $0.4584^{* *}$ & $0.3417^{* *}$ & -0.3487 & -0.4538 \\
\hline
\end{tabular}




\begin{tabular}{|l|l|l|l|l|}
\hline INFR & $0.5861^{* *}$ & 0.0541 & $0.1265^{* *}$ & $0.0547^{* * * *}$ \\
\hline Adjusted R-squared & 0.68 & 0.61 & 0.59 & 0.70 \\
\hline F-statistic & 45.11 & 52.17 & 49.83 & 45.93 \\
\hline Prob (F-statistic) & 0.00 & 0.00 & 0.00 & 0.00 \\
\hline
\end{tabular}

Note: $* * *, * *$ and $*$ denote $1 \%, 5 \%$ and $10 \%$ levels of significance, respectively.

Source: Author's compilation from E-Views.

Using fixed effects, financial development had a significant positive impact on energy consumption in model 1 and a non-significant positive effect on energy consumption in model 2. These results are supported by a study done by Fernandes and Reddy (2021) in the case of China.

Whilst model 3 shows a significant negative relationship running from financial development towards energy consumption, model 4 produced results which indicates that energy consumption was negatively but non-significantly influenced by financial development. The results are consistent with Aye and Edoja (2017) whose research revealed that financial development can avail more funding towards investment into clean energy sources which are energy efficient.

Across all the four models, human capital development had a significant positive impact on energy consumption, in line with Tsaurai (2019) whose study argued that high levels of human capital development spur industrialization and large-scale manufacturing activities in the economy, leading to more energy consumption.

The study shows that the complementarity between financial development and human capital development had a significant positive effect on energy consumption across all the four models. The results also mean that human capital development is a channel through financial development's positive influence on energy consumption was enhanced, consistent with Salim et al. (2017)'s argument (Table 1).

Trade openness's impact on energy consumption was found to be positive but nonsignificant across all the four models, results which resonates with Rasiah et al. (2018)'s argument. Economic growth was observed to have had a significant positive influence on energy consumption across all the four models, in line with Nindi and Odhiambo (2014) who argued that economic growth leads to more energy consumption in a more energy consumption reliant economy.

In model 1 and 2, a significant positive relationship running from FDI towards energy consumption was observed, consistent with Abdouli and Hammami (2017) whose study revealed that FDI inflows increases energy consuming economic activities such as infrastructural development, urbanization, manufacturing activities and industrialization. On the other hand, a non-significant negative impact of FDI on energy consumption was noted in model 3 and 4, in contradiction to the existing literature on the subject matter. 
Infrastructural development had a significant positive influence on energy consumption in model 1, 3 and 4 whilst model 2 shows a non-significant positive impact of infrastructural development on energy consumption. The results resonate with Yessengali and Murat (2018) whose research noted that infrastructural development related to roads maintenance and renovation of buildings consumes huge amounts of energy.

Table 8. Pooled OLS results

\begin{tabular}{|l|l|l|l|l|}
\hline & Model 1 & Model 2 & Model 3 & Model 4 \\
\hline FIN & $0.0056^{* *}$ & $0.2376^{*}$ & $0.6598^{*}$ & $0.2176^{* *}$ \\
\hline HCD & $0.3428^{*}$ & $0.2587^{*}$ & $0.2387^{*}$ & $0.3265^{* *}$ \\
\hline FIN.HCD & $0.4329^{* * *}$ & $0.5498^{* * *}$ & $0.5648^{* * *}$ & $0.0934^{* * *}$ \\
\hline OPEN & $0.6583^{* * *}$ & $0.6398^{*}$ & $0.4761^{*}$ & $0.4587^{*}$ \\
\hline GROWTH & $0.3429^{* *}$ & $0.2398^{*}$ & $0.5419^{*}$ & $0.3428^{*}$ \\
\hline FDI & -0.5698 & -0.5632 & -0.5639 & $0.4896^{* *}$ \\
\hline INFR & $0.4598^{* *}$ & 0.4598 & 0.2179 & $0.4328^{* *}$ \\
\hline Adjusted R-squared & 0.71 & 0.69 & 0.62 & 0.67 \\
\hline F-statistic & 41.98 & 51.14 & 49.09 & 42.45 \\
\hline Prob (F-statistic) & 0.00 & 0.00 & 0.00 & 0.00 \\
\hline
\end{tabular}

Note: $* * *, * *$ and $*$ denote $1 \%, 5 \%$ and $10 \%$ levels of significance, respectively.

Source: Author's compilation from E-Views.

In all the four models, financial development had a significant positive influence on energy consumption under the pooled OLS approach. The results were supported by Samuel et al. (2013) whose study noted that financial development spurs the number and scale of economic activities hence increasing the overall quantity of energy used in the economy. Human capital development's impact on energy consumption was also found to be positive and significant across all the four models, consistent with Tsaurai (2019) who argued that human capital development spur large-scale manufacturing activities and industrialization in the economy, leading to more energy consumption.

In line with Salim et al. (2017), the complementarity between financial development and human capital development influenced energy consumption in a positive and significant manner. In other words, the influence of financial development on energy consumption was found to have been enhanced by human capital development across all the four models.

A significant positive relationship running from trade openness towards energy consumption was also observed across all the four models, consistent with a study done by Ismail et al. (2017) in the case of ASEAN seven member countries. Economic growth was also noted to have had a significant positive effect on energy consumption, in line with a research done by Fernandes and Reddy (2021) in the case of Indonesia. 
Model 4 produced results which show that the impact of FDI on energy consumption was positive and significant, in line with Tang (2009) whose study observed that the inflow of foreign direct investment scales up urbanization, general level of manufacturing activities and infrastructural development activities, all of which consumes significant amount of energy. In contrast with available literature, model 1,2 and 3 shows that FDI had a non-significant negative influence on energy consumption.

Infrastructural development had a significant positive effect on energy consumption in model 1 and 4 whilst a non-significant positive relationship running from infrastructural development towards energy consumption was observed in model 2 and 3. The results support arguments which put forward by Yessengali and Murat (2018).

Table 9. Random Effects results

\begin{tabular}{|l|l|l|l|l|}
\hline & Model 1 & Model 2 & Model 3 & Model 4 \\
\hline FIN & 0.0659 & $0.3418^{* *}$ & $0.3428^{* *}$ & 0.0084 \\
\hline HCD & $0.3487^{*}$ & $0.5198^{*}$ & $0.1198^{* *}$ & $0.4582^{*}$ \\
\hline FIN.HCD & $0.6518^{* * *}$ & $0.0045^{* * *}$ & $0.0452^{* * *}$ & $0.5487^{* * *}$ \\
\hline OPEN & $0.5429^{* *}$ & 0.3889 & $0.2256^{* *}$ & 0.6532 \\
\hline GROWTH & $0.2387^{* * *}$ & 0.0045 & 0.4110 & $0.1167^{* * *}$ \\
\hline FDI & $0.6528^{* *}$ & -0.4587 & $0.3329-$ & $0.2317 * * *$ \\
\hline INFR & $0.1156^{* *}$ & 0.5418 & $0.4328^{* *}$ & 0.2317 \\
\hline Adjusted R-squared & 0.69 & 0.64 & 0.61 & 0.66 \\
\hline F-statistic & 43.87 & 53.83 & 43.14 & 40.32 \\
\hline Prob (F-statistic) & 0.00 & 0.00 & 0.00 & 0.00 \\
\hline
\end{tabular}

Note: $* * *, * *$ and $*$ denote $1 \%, 5 \%$ and $10 \%$ levels of significance, respectively.

Source: Author's compilation from E-Views.

Using random effects approach, financial development had a non-significant positive impact on energy consumption in model 1 whilst model 2, 3 and 4 produced results which show a significant positive relationship running towards energy consumption from financial development. The results are in line with findings produced by Samuel et al (2013), Fernandes and Reddy (2021) and Lefevre and Mainguy (2020).

Like findings produced by Mehrara et al. (2015) and Ergun et al. (2019), all the four models show that human capital development had a significant positive influence on energy consumption. Also, a significant positive relationship running from the complementarity variable (between financial and human capital development) towards energy consumption was observed, in support of Salim et al. (2017)'s argument.

Model 1 and 3 show that trade openness had a significant positive influence on energy consumption whilst model 2 and 4 reveal that energy consumption was affected by trade openness in a positive but non-significant manner. The results are in line with similar empirical research done by Ismail et al. (2017). Model 1 and 4 
show that economic growth had a significant positive effect on energy consumption yet model 2 and 3 reveal that the impact of economic growth on energy consumption was positive but not significant. The results resonate with earlier similar studies done by Lefevre and Mainguy (2020), Bohlmann and Inglesi-Lotz (2020), Ismail et al. (2017), Ergun et al. (2019) and Inglesi-Lotz and Pouris (2016).

Consistent with Ergun et al. (2019) whose empirical research noted that FDI led to an increase in the usage in renewable energy, model 1 and 4 shows that FDI had a significant positive impact on energy consumption. Yet, model 2 and 3 reveal that the impact of FDI on energy consumption was negative and non-significant, in contradiction with most of the available literature on the subject matter.

Model 1 and 3 shows that infrastructural development had a significant positive impact on energy consumption whilst model 2 and 4 produced results which reveal a non-significant positive effect of infrastructural development on energy consumption. The results resonate with earlier similar research on the subject matter done by Yessengali and Murat (2018).

Table 10. Fully Modified Ordinary Least Squares (FMOLS) results

\begin{tabular}{|l|l|l|l|l|}
\hline & Model 1 & Model 2 & Model 3 & Model 4 \\
\hline FIN & 0.3421 & 0.2267 & 0.0956 & 0.0906 \\
\hline HCD & $0.3428^{* *}$ & $0.4538^{*}$ & $0.3479^{* *}$ & $0.5498^{*}$ \\
\hline FIN.HCD & $0.1156^{* * *}$ & $0.2267^{*}$ & $0.2359^{*}$ & $0.4376^{* *}$ \\
\hline OPEN & 0.2376 & $0.3267^{* *}$ & 0.0894 & $0.0647^{* *}$ \\
\hline GROWTH & $0.1156^{* * *}$ & $0.4537^{* * *}$ & $0.3498^{* * *}$ & $0.4387^{* * *}$ \\
\hline FDI & -0.3427 & -0.2287 & $0.2278^{* *}$ & $0.1178^{* *}$ \\
\hline INFR & $0.5648^{* *}$ & $0.2367^{* *}$ & $0.0547^{* * *}$ & $0.2378^{* * *}$ \\
\hline Adjusted R-squared & 0.73 & 0.75 & 0.70 & 0.67 \\
\hline F-statistic & 42.67 & 51.98 & 46.89 & 41.34 \\
\hline Prob (F-statistic) & 0.00 & 0.00 & 0.00 & 0.00 \\
\hline
\end{tabular}

Note: $* * * * *$ and $*$ denote $1 \%, 5 \%$ and $10 \%$ levels of significance, respectively.

Source: Author's compilation from E-Views.

Using FMOLS approach, financial development had a non-significant but positive influence on energy consumption across all the four models as generally supported by most recent literature (Fernandes and Reddy, 2021). In line with available literature (Mehrara et al. 2015), human capital development was also found to have had a significant positive influence on energy consumption in all four models. Salim et al. (2017)'s study also resonates with this study which show that the complementarity variable had a significant positive effect on energy consumption in all four models.

Model 1 and 3 shows that trade openness had a non-significant positive impact on energy consumption whilst a significant positive relationship running from trade openness towards energy consumption was observed in model 2 and 4. These results are supported by literature (Ismail et al. 2017; Rasiah et al. 2018). In support of 
findings produced by Ergun et al. (2019) and Lefevre and Mainguy (2020), energy consumption was driven up by economic growth across all the four models.

In contrast with available literature, model 1 and 2 shows a non-significant negative influence of FDI on energy consumption. However, model 3 and 4 shows that FDI had a significant positive effect on energy consumption, in line with earlier empirical researchers such as Ergun et al. (2019). Consistent with Yessengali and Murat (2018) and Reddy et al. (2001), this study reveals that a significant positive relationship running from infrastructural development towards energy consumption exists across all the four models.

\section{Concluding Remarks}

This study investigated the determinants of energy consumption in BRICS countries using panel data analysis methods (fixed effects, FMOLS, pooled OLS, random effects) with panel data ranging from 1996 to 2018. Under fixed effects, financial development was found to have had a significant positive influence on energy consumption in model 1 and a significant negative effect on energy consumption in model 3. Human capital development, financial development, the interaction between financial and human capital development and economic growth were all found to have had a significant positive influence on energy consumption across all the four models. FDI had a significant positive effect on energy consumption in model 1 and 2 whilst infrastructural development had a significant positive influence on energy consumption in model 1, 3 and 4 .

Under pooled OLS methodology, financial development, human capital development, interaction variable, trade openness and economic growth were found to have had a significant positive impact on energy consumption across all models. FDI's significant positive influence on energy consumption was observed in model 4 only whilst infrastructural development had a significant positive effect on energy consumption in model 1 and 4 . Under random effects, financial development influenced energy consumption in a significant positive manner in model 2 and 3. Both human capital development and the interaction term separately had a significant positive impact on energy consumption across all the four models whilst trade openness and infrastructural development's influence on energy consumption was positive and significant in model 1 and 3. Yet economic growth and FDI were found to have had a significant positive influence on energy consumption in model 1 and 4.

Under FMOLS, four variables which had a significant positive effect on energy consumption across all the four models include human capital development, the interaction term, economic growth, and infrastructural development. Whilst trade openness had a significant positive impact on energy consumption in model 2 and 4 , FDI's impact on energy consumption was observed to be positive and significant under model 3 and 4 . BRICS countries are therefore urged to design and implement 
policies aimed at enhancing human capital development, the complementarity between financial and human capital development, economic growth and infrastructural development in order to increase renewable and fossil fuel energy usage (energy usage that preserves the ecosystem and promotes sustainable growth).

\section{References:}

Abdouli, M., Hammami, S. 2017. Exploring links between FDI inflows, energy consumption and economic growth: Further evidence from MENA countries. Journal of Economic Development, 42(1), 95-117.

Alter, N., Syed, S.H. 2011. An Empirical Analysis of Electricity Demand in Pakistan. International Journal of Energy Economics and Policy, 1(4), 116-139.

Ateba, B.B. Prinsloo, J.J., Fourie, E. 2018. The impact of energy fuel choice determinants of sustainable energy consumption of selected South African households. Journal of Energy in Southern African, 29 (3), 51-65.

Aye, G.C., Edoja, P.E. 2017. Effect of economic growth on CO2 emission in developing countries: Evidence from a dynamic panel threshold regression model. General and Applied Economics. https://doi.org/10.1080/23322039.2017.1379239.

Azam, M., Khan, A.Q. Zafeiriou, E., Arabatzis, G. 2016. Socio-economic determinants of energy consumption: An empirical survey for Greece. Renewable and Sustainable Reviews, 57, 1556-1567.

Bohlmann, J.A., Inglesi-Lotz, R. 2020. Examining the determinants of electricity demand by South African households per income level. Economic Research Southern Africa (ERSA) Working Paper. Series Number 833.

Elimam, H. 2020. Determinants of Energy Consumption in Saudi Arabia and its Role in Decreasing the Misuse of Environmental Resources. SSRG

International Journal of Economics and Management Studies, 7(3), 47-58.

Ergun, S.J., Owusu, P.A., Rivas, M.F. 2019. Determinants of renewable energy consumption in Africa. Environmental Science and Pollution Research International, 26(15), 15390-15405.

Fernandes, K., Reddy, Y.V. 2021. Determinants of energy consumption in newly industrialized countries of Asia. International Journal of Energy Economics and Policy, 11 (1), 93-100.

Fuerst, F., Kavarnou, D., Singh, R., Adan, H. 2020. Determinants of energy consumption and exposure to energy price risk: A UK study. Z Immobilienokonomie, 6, 65-80.

Grossman, G.M., Krueger, A.B. 1991. Environmental İmpacts of a North American Free Trade Agreement. National Bureau of Economic Research, Working Paper Number 3914.

Huang, B.N., Hwang, M.J., Yang, C.W. 2008. Causal relationship between energy consumption and GDP growth revisited: A dynamic panel data approach. Ecological Economics, 6(7), 41-54.

Im, K.S., Pesaran, M.H., Shin, Y. 2003. Testing unit roots in heterogeneous panels. Journal of Econometrics, 115(1), 53-74.

Inglesi-Lotz, R., Pouris, A. 2016. On the causality and determinants of energy and electricity demand in South Africa: A review. Energy Sources, Part B: Economics, Planning and Policy, 11(7), 626-636.

Ismail, M.T., Mahmud, N., Rahman, R.A. 2017. The determinants of electricity consumption 
for ASEAN countries. Malaysian Journal of Fundamental and Applied Sciences, Special Issue on Some Advances in Industrial and Applied Mathematics, 331339.

Kim, M. 2018. Characteristics and determinants of electricity consumption level of households in Korea. Energy Reports, 4, 70-76.

Kwakwa, P.A. 2018. Analysis of the determinants of electricity consumption in Benin. Journal of Energy Management and Technology, 2(3), 42-59.

Lefevre, B., Mainguy, G. 2020. Urban transport energy consumption: Determinants and strategies for its reduction. Cities and Climate Change, 2(3), 1-17.

Levin, A., Lin, C.F., Chu, C.S.J. 2002. Unit root tests in panel data: Asymptotic and finitesample properties. Journal of Econometrics, 108(1), 1-24.

Liddle, B. 2004. Demographic dynamics and per capita environmental impact: Using panel regressions and household decompositions to examine population and transport. Population Environment Journal, 26(1), 23-29.

Liu, Y. Zhou, Y., Wu, W. 2015. Assessing the impact of population, income, and technology on energy consumption and industrial pollutant emissions in China. Applied Energy, 155, 904-917.

Mehrara, M., Rezaei, S., Razi, D.H. 2015. Determinants of Renewable Energy Consumption among ECO countries, Based on Bayesian Model Averaging and Weightedaverage Least Square. International Letters of Social and Humanistic Sciences, $55,96-109$.

Nindi, A.G., Odhiambo, N.M. 2014. Energy consumption and economic growth in Mozambique: An empirical investigation. Environmental Economics, 5(4), 82-92.

Premakumara, G.S. 2013. Patterns and determinants of energy consumption in Karnataka. International Journal of Scientific Research, 2(7), 110-112.

Rahut, D.B., Mottaleb, K.A., Ali, A. 2017. Household energy consumption and its determinants in Timor-Leste. Asian Development Review, 34(1), 167-197.

Rasiah, R., Guptan, V., Habibullah, M.S. 2018. Evaluating the impact of financial and economic factors on environmental degradation: A panel estimation study of selected ASEAN countries. International Journal of Energy Economics and Policy, 8(6), 209-216.

Reddy, A.K.N., Anand, Y.P., D’Sa, A. 2001. Energy for a sustainable road/rail transport system in India. Energy for Sustainable Development, 4(1), 29-44.

Salim, R., Yao, Y., Chen, G.S. 2017. Does human capital matter for energy consumption in China? Energy Economics, 67(Supplement C), 49-59.

Samuel, Y.A., Manu, O., Wereko, T.B. 2013. Determinants of energy consumption: A review. International Journal of Management Sciences, 1(12), 482-487.

Sineviciene, L., Sotnyk, I., Kubatko, O. 2017. Determinants of energy efficiency and energy consumption of Eastern Europe post-communist economies. Energy and Environment, 28 (8), 870-884.

Sofia, T., Paolo, B. Francesca, D., Luca, C., Marina, E., Nicola, L., Tiago, R.S., Paolo, Z. 2019. Analysis of the EU residential energy consumption: Trends and determinants. Energies, 6(12), 1065-1088.

Tang, C.F. 2009. Electricity consumption, income, foreign direct investment, and population in Malaysia: New evidence from multivariate framework analysis. Journal of Economic Studies, 36(4), 371-382.

Tembo, J. 2018. Regional financial integration and its impact on financial sector development: The case of Southern Africa. Unpublished Doctoral Thesis, University of South Africa. 
Tsaurai, K. 2018. Complementarity between foreign aid and financial development as a driver of economic growth in selected emerging markets. Comparative Economic Research. Central and Eastern Europe, 21(4), 45-61.

Tsaurai, K. 2019. The impact of financial development on carbon emissions in Africa. International Journal of Energy Economics and Policy, 9(3), 144-153.

Xia, X.H., Hu, Y. 2012. Determinants of electricity consumption intensity in China: Analysis of Cities Sub-province and Prefecture levels in 2009. Energy Economics and Policy, Article ID 496341. https://doi.org/10.1100/2012/496341.

Yessengali, O., Murat, I. 2018. The impact of financial development on energy demand in transitional economies. Global Economy Journal, 18(3).

Zaharia, A., Diaconeasa, M.C., Brad. L., Ladaru, G., Ioanas, C. 2019. Factors influencing energy consumption in the context of sustainable development. Sustainability, 11(4147), 1-28. 